\title{
Idiosyncratic deals in less competitive labor markets: testing career i-deals in the Greek context of high uncertainties
}

Article

Accepted Version

Katou, A. A., Budhwar, P. S. and Patel, C. (2021) Idiosyncratic deals in less competitive labor markets: testing career i-deals in the Greek context of high uncertainties. The International Journal of Human Resource Management, 32 (17). pp. 37483775. ISSN 1466-4399 doi:

https://doi.org/10.1080/09585192.2020.1759672 Available at https://centaur.reading.ac.uk/90738/

It is advisable to refer to the publisher's version if you intend to cite from the work. See Guidance on citing.

Published version at: http://dx.doi.org/10.1080/09585192.2020.1759672

To link to this article DOI: http://dx.doi.org/10.1080/09585192.2020.1759672

Publisher: Routledge

All outputs in CentAUR are protected by Intellectual Property Rights law, including copyright law. Copyright and IPR is retained by the creators or other copyright holders. Terms and conditions for use of this material are defined in the End User Agreement. 


\section{CentAUR}

Central Archive at the University of Reading

Reading's research outputs online 
Idiosyncratic deals in less competitive labor markets:

Testing career I-deals in the Greek context of high uncertainties

Anastasia A. Katou (corresponding author)

Associate Professor of Organizational Strategy

School of Business Administration

University of Macedonia

Thessaloniki 540 06, Greece

Email: akatou@uom.edu.gr

Pawan S. Budhwar

Professor of International HRM

Aston Business School

Aston University

Birmingham B4 7ET, UK

Email: p.s.budhwar@aston.ac.uk

\section{Charmi Patel}

Associate Professor in HRM

Henley Business School

University of Reading

Reading RG6 6UD, UK

Email: charmi.patel@henley.ac.uk 


\title{
Idiosyncratic deals in less competitive labor markets: \\ Testing career I-deals in the Greek context of high uncertainties
}

\begin{abstract}
This study investigates the impact of pre-hiring (ex-ante) and after-hiring (ex-post) negotiation on organizational citizen behavior (OCB), through three serially connected relationships: (1) between the timing of negotiation and career i-deals (idiosyncratic deals), moderated by feelings of self-worth; (2) between career i-deals and OCB, mediated by psychological contract fulfillment, and employee organizational commitment; and (3) between employer and employee psychological contract fulfillment, mediated by employee organizational commitment. To do so, it utilizes the social exchange theory, and a sample of 1768 employees working within 162 private organizations in the current context of high economic and financial uncertainties in Greece. Using a comprehensive framework tested by structural equation multilevel modeling, the study conclusions imply that in the less-competitive labor market of Greece, (a) core self-evaluation (CSE), which reflect individual differences, do not moderate the relationship between timing of negotiation and career i-deals, but independently predicts career i-deals; (b) career i-deals influence psychological contract expressed in promises fulfillment (PF); employee organizational commitment constitutes the binding epicenter of the relationships between employer and employees PF and between career i-deals and OCB. Based on these findings, the study has several theoretical and practical implications for high uncertainty contexts.
\end{abstract}

Keywords: Idiosyncratic deals, Ex-ante and ex-post negotiations, Career i-deals, Psychological contracts, Employee outcomes, High uncertainties, Greece 


\section{Introduction}

Research on business and human resource management (HRM) in contexts of high uncertainties although is fragmented among many disciplines, there has been a great growth in recent years. For example, studies investigate the influence of turbulent times on HRM (e.g., Nijsseen and Paauwe, 2012), voice and silence (e.g., Prouska and Psychogios, 2018a; Prouska and Psychogios, 2018b; Schlosser and Zolin, 2012), adverse working conditions (e.g., Psychogios, Nyfoudi, Theodorakopoulos, Szamosi, and Prouska, 2019); and recessionary bundles (e.g., Teague and Roche, 2013). However, research on the influence of high uncertainty contexts on i-deals remains scarce. Questions focusing on changes of the bargaining power between employers and employees, during uncertain situations created by economic and financial crisis, are still unanswered. In particular, the influence of these changes in the bargaining power of employers and employees on HR outcomes has not been fully examined (Wood, Cooke, Demirbag, and Kwong, 2018).

This study seeks to recognize the impact of changes in the bargaining power between employers and employees, expressed by i-deals negotiations, on employee attitudes and behaviors in a representative environment of high uncertainties like that of Greece. Considering that "high uncertainly contexts do not affect different sectors uniformly" (Wood et al., 2018, p. 1370), the research framework is tested using data from a large national sample of Greece, covering private organizations in three sectors: manufacturing (e.g., home commodities production, food processing, electricity, mining); services (e.g., tourism, hotel and hospitality, health, education, banking); and trade (e.g., super markets, multi stores, distributive trades). Additionally, taking into consideration that individuals follow different paths in managing ideals negotiations, our study covers individuals with different characteristics (e.g., related to demography and personality) and different psychological tendencies (e.g., psychological contract) in coping successfully responsibilities in turbulent situations (Wood et al., 2018, p. 
1367). Overall, the current study investigates the serially mediating process of i-deals content and psychological contract (PC), in the relationship between the timing of i-deals negotiation and HR outcomes in periods of high uncertainty.

Specifically, since the influential study by Rousseau (2005), investigations (e.g., Anand, Vidyarthi, Liden, and Rousseau, 2010; Ho and Kong, 2015; Hornung, Rousseau, and Glaser, 2009; Hornung, Rousseau, Weigl, Muller, and Glaser, 2014; Liu, Lee, Hui, Kwan, and Wu, 2013) have verified that i-deals are arranged in organizations to improve attitudinal (e.g., motivation, organizational commitment) and behavioral (e.g., work engagement, and organizational citizenship behavior - OCB) employee outcomes. I-deals refer to particular employment arrangements that are adapted to the personal preferences and requirements of employees (Ng and Feldman, 2015). Considering that i-deals content refers to the particular resources they include (Rousseau, Ho, and Greenberg, 2006), it has been supported that the content of i-deals may differ. Accordingly, a typology for i-deals content has been proposed indicating task $i$-deals (i.e., the customized arrangements individual employees bargain to make their job content more inspiring and pleasant), career $i$-deals (i.e., the customized arrangements individual employees negotiate for advancing professional careers), and flexibility i-deals (i.e., the personalized arrangements individual employees negotiate for achieving time working schedules that better fit their requirements and preferences) (Hornung et al., 2014). Later, this typology has been extended including location i-deals (i.e., unique job arrangements that permit staff to get involved with the work in geographical places far from the office) (Ho and Kong, 2015; Liao, Wayne, and Rousseau, 2016) and financial $i$-deals (i.e., the payment arrangements that fit personal requests) (Rosen, Slater, Chang, and Johnson, 2013).

In spite of the development of i-deals literature, three important gaps still remain. First, although the structure of the connection between timing of negotiation and i-deals content is 
important for attracting and retaining talent, it may vary substantially due to differences in the national context of labor markets where negotiation is taking place (Rousseau, Hornun, and Kim, 2009). In particular, few studies have investigated this connection in less competitive labor markets experiencing severe economic and financial crisis and immense economic uncertainties (like Greece, amongst many others). Less competitive labor markets refer to the national contexts where the bargaining power in the negotiating process leans in favor of employers. In most cases, i-deals research has been focused within the context of competitive labor markets, such as Germany (e.g., Hornung, Rousseau, and Glaser, 2008; 2009), the USA (e.g., Lai, Rousseau, and Chang, 2009; Ng and Feldman, 2010) and the UK (e.g., CoyleShapiro and Conway, 2005), where the bargaining power in the negotiating process leans in favor of employees. However, the 2008 global economic crisis produced high unemployment in many countries and people had to adapt to new economic realities (Bal and Dorenbosch, 2015). In these cases, where unemployment is high, and the labor market is accordingly considered to be less competitive, the bargaining power in the negotiating process leans in favor of employers. Thus, in stressful economic times of high uncertainties, it's an opportunity to examine the influence of the timing of $\mathrm{i}$-deals negotiation and their content on employee outcomes.

Accordingly, the purpose of this research is to examine the relationship between i-deals and employee outcomes in the unique context of Greece, which being under severe economic and financial crises, with high unemployment, is categorized as a less competitive labor market (CIPD, 2016). This study focuses only on career i-deals, because we argue that in turbulent times, individuals put more emphasis on work safety which is reflected more by careers development than by other types of i-deals. In other words, employers grand career i-deals to those individuals who are valuable and trustworthy, and as such they support them and plan to keep them for longer periods in the organization (Rousseau, 2005). Individuals feel this practice 
of the organizations as a message that they are here to stay, thus reflecting job security in an adverse environment (Liao et al., 2016). Accordingly, the boundary conditions of our study distinguish between competitive and less competitive labor markets and the boundary conditions function refers to the accuracy of the predictions in the context of the less competitive labor markets (Busse, Kach, and Wagner, 2017).

Second, although i-deals are distinct from psychological contracts (Liao et al., 2016), and despite the increasing amount of research about both i-deals and psychological contracts (PCs) in describing the employment relationship (e.g., Kasekende, Munene, Ntayi, and Ahiauzu, 2015; Lee and Hui, 2011), few studies have treated i-deals to be among the antecedents of PCs (Sturges, Conway, Guest, and Liefoodghe, 2005). On the contrary, most studies were treating HRM policies to be the major predictors of PCs (Suazo, Martinez, and Sandoval, 2009). This is unexpected, taking into consideration the high increase in concern for outcomes from i-deals negotiation (Bal and Dorenbosch, 2015) and the fact that employees start developing their PCs about an organization even prior to hiring, and that this is further developed after hiring (Rousseau, 2005). Psychological contract is defined as "an individual's system of belief, shaped by the organization, regarding terms of an exchange agreement between him/herself and the organization" (Rousseau and Greller, 1994, p. 385). As such, it is argued that PC is appropriate to separate labor market, reflecting the tendency of individuals to pursue i-deals from their employers. However, considering that i-deals content expresses the interests of both parties in negotiation, we argue that the content of $i$-deals constitutes the core mechanism that connects i-deals negotiation and PC. This is because i-deals content is the result of i-deals negotiation, which in turn establishes the quality of the employment relations reflected in the PC. Empirically, we may say that this is expressed in the objective nature of i-deals content constructs and in the subjective nature of PC constructs. Accordingly, we address this gap by investigating whether career i-deals mediate the timing of i-deals negotiation - PC relationship 
(Lee and Hui, 2011).

Third, research till now supports the view that the effects of i-deals on employee outcomes depend on their content (Hornung et al., 2008). Although, relatively few studies have been recently conducted in less developed countries such as the Philippines (Las Heras, Rofcanin, Bal, and Stollberger, 2017a; Las Heras, van der Heijden, de Jong, and Rofcanin, 2017b) and in under studied contexts such as Italy ( $\mathrm{Ng}$ and Lucianetti, 2016), it is usually supported that in cases where employees are granted i-deals that meet their prospects they will respond positively (Ng and Feldman, 2010; Sturges, 2012). Additionally, although i-deals are accepted to be a win-win case for both employers and employees (Rousseau, 2005), it is argued that this process depends upon the complexity of the environmental work context and the specific costs attached to it (Vidyarthi, Chaudhry, Anand, and Liden, 2014). Further, based on the social exchange expectation (Blau, 1964) between the employee and the employer, a number of the individual level employee outcomes attributed to i-deals are also credited to PCs (Rosen et al., 2013). Nevertheless, relatively little is known about why and how employees improve their outcomes as a reaction to getting i-deals (Ng and Feldman, 2015). However, the strength of this response may depend on the characteristics of the individuals to whom i-deals have been granted ( $\mathrm{Ng}$ and Feldman, 2010). This may be true, and we argue that the characteristics of the individuals, such as gender, age, education, hierarchical position and personality, may be also important during i-deals negotiation. For example, apart from the type of the labor market, the feelings of self-worth may play a major role in how individuals conduct their i-deals negotiation. For that reason, we consider the state of self-worth as another boundary condition between negotiation and career i-deals (Busse et al., 2017) in periods of economic uncertainty.

Taking into consideration the above and based on the social exchange theory (SET) and the norm of reciprocity (Blau, 1964), this study investigates three serially connected 
relationships. First, between the timing of negotiation and career i-deals, moderated by feelings of self-worth (Ng and Feldman, 2010). We believe that self-worth illuminates this relationship because most studies that use CSE are focused on the 'one-step-later' relationship, between ideals content and employee attitudes and behavior, bypassing the influence of CSE between the initiating influence of timing of negotiation on career i-deals ( $\mathrm{Ng}$ and Feldman, 2010). Second, between career i-deals and OCB, mediated by psychological contract fulfillment (Bal, De Jong, Jansen, and Bakker 2012), and employee organizational commitment. We consider that this angle of looking at things is important because most studies have investigated the direct influence of career i-deals on OCB (e.g., Liao et al., 2016), without offering new insights into this relationship. Third, employer and employee psychological contract fulfillment, mediated by employee organizational commitment (Katou and Budhwar, 2012). The rationale for the choice of the specific constructs and the proposed relationships is detailed in the next section. Thus, while scholars are more likely to examine how PC (and often its breach) leads to an employee negotiating i-deals ( $\mathrm{Ng}$ and Feldman, 2012), we investigate the opposite, considering it is rather difficult for this sequence of events to take place in a less competitive labor market with high unemployment, produced by economic and financial crisis, and as such, we exclude the possibility of reverse causality. Finally, these serially connected processes are tested in the current context of high economic and financial uncertainties in Greece, using multilevel structural equation analyses due to the nested nature of data (Muthen and Muthen, 2014).

\section{Research framework and hypotheses}

\section{The Greek context}

Greece although is a member-state of the European Union, it has been seriously affected by the 2008 economic and financial crises. Large fiscal and current account deficits have been running for many years and inefficacy and corruption in most aspects of public administration has 
resulted in inefficient organizations. A total of 244,712 firms have been closed in the period $2008-2015$, with a loss of 842,670 jobs in that period. The decrease in the number of businesses comes from bankruptcies or closure of businesses as well as from companies that have moved their operations abroad (for details see Bellos, 2017).

In this bleak picture, Greek firms are trying to avoid closure and employees are struggling to stay in employment. Many small and medium enterprises (SME) ignore labor law legislations and compensate employees to lower levels than the current labor laws indicate (Wood, Szamosi, Psychogios, Sarvanidis, and Fotopoulou, 2015). Greece, being a memberstate of the Euro-zone, and having agreed on a Memorandum of Economic and Financial Practices with the three institutions (i.e., EC, IMF, and ECB), had to implement policies to reinforce market assurance and make the economy more competitive. In this respect, the working conditions changed by relaxing the standard level of the weekly eight hours, cutting reward rates, extending the working week time, and intensifying work conditions (Wood et al., 2015). In general, the worker rights seemed to be more precarious in Greek SME than in other countries (Psychogios and Wood, 2010).

Nevertheless, the extent to which employment terms and conditions are negotiable in Greece may depend on its labor market characteristics. Greece is considered to belong to a low degree zone of negotiability, which refers 'to the conditions of employment available for negotiation by workers and their employer' (Rousseau, 2001, p. 264). This is because most employment conditions are pre-specified by the Eurozone central directives. But, considering the high level of unemployment in Greece (about 25 percent), the bargaining power of individuals (employed or unemployed) is rather weak, reflecting a less competitive labor market.

The timing of negotiation and career $i$-deals 
I-deals can be negotiated either before hiring (ex-ante), or after hire (ex-post) or both prior and during employment (Rousseau, 2005). In general, it is argued that people usually tend to negotiate ex-post i-deals more often than ex-ante i-deals (Rousseau et al., 2006). This is because ex-ante negotiation is taking place only at a limited time, for example before hiring period, may be considered to be a static phenomenon. In contrast, ex-post negotiation may be considered to be dynamic because it is taking part during the on-going employment relationship between an employer and employees (Chand, Budhwar, and Katou, 2017). However, negotiation of i-deals is linked with the individual differences which are usually reflected in self-worth (e.g., core self-evaluations) and demographics (e.g., age, gender, education) ( $\mathrm{Ng}$ and Feldman, 2010), along with the power of the two parties (i.e. the employee and the employer) involved in negotiation which is usually based on the characteristics of the labor market (e.g., more or less competitive) (Rousseau et al., 2006).

Core self-evaluations (CSE) refer to the basic properties people hold about themselves (Judge, Locke, and Durham, 1997). Four specific traits indicate CSE. Self-esteem indicates the extent to which individuals believe that they are people of worth. Self-efficacy indicates the extent to which individuals believe that they are able to efficiently perform tasks. Emotional stability is the extent to which individuals believe that they are mentally healthy and useful. Locus of control is the extent to which individuals believe that they can control their own future. In general, individuals who believe to have high assessments about these four CES traits are considered to have high self-evaluation ( $\mathrm{Ng}$ and Feldman, 2010).

The construct of CSE has been used in earlier research mostly as an independent variable that influences employee outcomes (Judge, Locke, Durham, and Kluger, 1998). In later research, studies tried to investigate the moderating effect of CES in various employee relationships and the independent variable effects on i-deals (Chand et al., 2017). It is argued that individuals with feelings of high self-evaluation negotiate strongly both ex-ante and ex- 
post i-deals believing that they are entitled to these i-deals. On the contrary, individuals with feelings of low self-evaluation negotiate weak ex-ante or ex-post ideals, and if taken together, these i-deals will feel much obligated and as such they will try strongly to reciprocate $(\mathrm{Ng}$ and Feldman, 2010).

In competitive labor markets (with low unemployment rates), where the supply of certain skills and abilities is lower than demand, the power is more on the side of highly marketable employees (Rousseau, 2001). This is because employers trying to attract talent are likely to grant ex-ante i-deals to important human resources according to their knowledge, skills and abilities (KSAs), reflecting their market value (Rousseau et al., 2006). Additionally, in such markets employers in trying to retain productive employees usually grant ex-post ideals to employees after they have proven to be honest and important (Rousseau, 2005). Thus, employers being afraid of losing employees that have proven to be good and are difficult to replace, put more emphasis on ex-post i-deals than on ex-ante i-deals. Accordingly, in such a context, it is usually assumed that the degree of ex-post i-deals is higher than the degree of exante i-deals (Rousseau et al., 2009).

On the contrary, in less competitive labor markets such as those existing over the last 10 years in Greece due to economic crisis (e.g., financial crises, deep recession), the power is more on the side of the employer. This is because in such markets the supply of certain skills is higher than demand, resulting in high unemployment and low wages and salaries. Thus, candidates or existing employees may feel weak in negotiating either ex-ante or ex-post i-deals. For example, candidates before hire may think that they may not get the job by pushing negotiation too hard, otherwise another candidate with similar qualifications may be chosen. Similarly, workers in jobs may fear being substituted by others from the unemployed candidate pool if they push negotiation too hard for their demands. Accordingly, the power of negotiation is with employers in such markets. 
It is further argued that negotiation in terms of timing and i-deals with respect to content are interdependent (Rousseau et al., 2009). Research referring to the timing of negotiation and i-deals usually considers that the employment relationship takes place in a competitive labor market context. In this context, employees during ex-ante negotiation are usually concentrating on getting tangible i-deals such as payment and work schedules. On the contrary, employees during ex-post negotiation is likely to concentrate on getting intangible i-deals such as mentoring and work promotion paths (Rousseau et al., 2009). However, in less-competitive labor markets this may not be true as individuals may feel weak in negotiating either ex-ante or ex-post i-deals. Therefore, we argue that the employment relationship is quasi-symmetric between employed and unemployed individuals in markets with high unemployment.

All types of i-deals content (i.e. task, career, flexibility, location, and financial i-deals) are usually granted in competitive labor markets (Ho and Kong, 2015; Hornung et al., 2014; Liao et al., 2016; Rosen et al., 2013). However, in less competitive labor markets this may not hold. In particular, in less competitive labor markets, such as Greece, unemployed people trying to find a job do not have the power to enter negotiation. They just want to get the job. This is because under the austerity conditions that usually prevail in these markets, individuals believe that they do not have the luxury to ask for work that fits their personal strengths (i.e., task ideals) or work that is customized to their needs (i.e., flexibility i-deals). Individuals with high self-evaluation may accept temporarily any ex-ante i-deal, or employed people being scared of losing their job may accept any ex-post i-deal postponing temporarily career opportunities. This is because individuals try to reconcile future career targets with current other i-deals priorities (King, 2004). Individuals do not have the privilege to ask for location i-deals because they also know that employers, especially in SMEs such as those of Greece, do not value location i-deals. This is based on the supposition that employers tend to identify location ideals with low efficient activities when people work within the family context (Las Heras et 
al., 2017a). Individuals do not have the authority to request for financial i-deals because they know that other people from the unemployment pool are ready to accept smaller wages (Kousta and Stamati, 2012). Generally, people are less likely to talk about and seek for financial i-deals in such settings because of secrecy surrounding them and people do not often like to talk about rewards and compensation (Marescaux, De Winne, and Sels, 2019).

In summary, taking into consideration that in both competitive and less competitive labor markets with high uncertainties "individuals are becoming increasingly responsible for managing their own careers (Briscoe and Hall, 2006)" (cited in Ng and Feldman, 2010, p. 419), and that seek to find jobs or keep their jobs that prescribe future safety. This study concentrates on career i-deals for both theoretical and practical reasons because it is not possible to include other types of i-deals in one paper. This is because career i-deals by referring to personal goals, development opportunities and professional advancement (Schaufeli, Salanova, GonzalezRoma, and Bakker, 2002) make them to feel more secure. Additionally, when individuals develop in the organization the employer has more information about them (and presumably have invested more in the employee) than when the individual is new to the organization. Thus, the extent of the static phenomenon of ex-ante negotiation is less than the extent of the dynamic ex-post negotiation. Nevertheless, the relationship between ex-ante or ex-post negotiation and career i-deals may be moderated by CSE. Thus, taking into account that a small number of studies have investigated career i-deals with respect to the timing of negotiation (Hornung et al., 2010; Liao et al., 2016), we hypothesize that:

Hypothesis 1: (a) CSE moderates the relationship between ex-ante negotiation and career $i$ deals, and (b) CSE moderates the relationship between ex-post negotiation and career $i$-deals, such that the relationships are stronger for individuals high on CSE.

Career i-deals, organizational commitment and psychological contract 
Although i-deals are related to psychological contracts (Lee and Hui, 2011), the two concepts are undoubtedly different (Hornung et al., 2014). After successful negotiation, i-deals constitute specific and official arrangements that enable employees to acquire things that their peers did not get (Guerrero, Bentein, and Lapalme, 2014). In contrast, the PC represents an individual's beliefs regarding employee and employer obligations, which refer to the terms and conditions that constitute the employment relationship (Robinson and Rousseau, 1994). In particular, the PC of an employee refers to his/hers beliefs about the obligations of the employer to him/her (also called inducements) and his/hers obligations to the employer (also called contributions) (Bordia, Restubog, Bordi, and Tang, 2014). PCs are considered to be subjective to a great extent (McDonald and Makin, 2000). However, despite this subjectivity there are many common features that usually classify PCs into two categories. The first category is called transactional contracts and it includes features such as performance-based pay and competitive wage rates, which have the characteristics of being specific, short-term, and monetary-in-nature beliefs. This second category is called relational contracts and it includes features such as career development, job security commitment, trust, and loyalty, which have the characteristics of being less specific, long-term and monetary and non-monetary-in-nature beliefs (Rousseau, 1995).

Despite the economic turbulence and high unemployment in less competitive labor markets, talent remains a fundamental source of competiveness for companies across industries. Strategic HRM has become increasingly important means for realizing the value that exists in employees. Scholars (e.g., Kroon, Freese, and Schalk, 2015) position i-deals as a strategic choice within strategic HRM and introduce i-deals as part of HRM policies in the organization. They argue that strategic HRM combines standardized HRM practices and ideals as part of the process of managing human capital. As such, taking into consideration that PCs are important predictors of employee outcomes most studies support that strategic HRM 
practices are major predictors of PCs (Suazo et al., 2009). In particular, Guest (2004) supports the view that PCs are influenced over time by i-deals. In practice, employees negotiate i-deals to adjust their jobs to better suit their personal circumstances and thus shape the employeremployee relationship reflected in their PC (Meijerink, 2014). In simple words, career i-deals influence employer and employee promises fulfillment because employers having granted career i-deals try to keep their promises, and employees having got career i-deals try to reciprocate by also keeping their promises. In this study, we focus on the employer promises fulfillment as perceived by employees, who are likely to reciprocate by fulfilling their own promises (Conway and Briner, 2005; de Jong et al., 2009; Katou and Budhwar, 2012). This is due to the fact that the outcomes of the psychological contract are more strongly related to the fulfillment of promises than to promises per se (Lambert, Edwards and Cable, 2003; Katou and Budhwar, 2012).

Considering that $\mathrm{i}$-deals constitute a dimension of the strategic HRM process of managing human capital and that PCs can be considered as obligations that gush from the achievement of i-deals (Lee, Liu, Rousseau, Hui, and Chen, 2011), we argue that career i-deals positively influence organizational commitment both directly and indirectly through PCs. Meyer and Allen (1991) describe organizational commitment with respect to the extent an individual is attached to the organization and "has at least three separable components reflecting: (a) a desire (affective commitment), (b) a need (continuance commitment), and (c) an obligation (normative commitment) to maintain employment in an organization" (p. 61). Career i-deals directly influence organizational commitment, because "perceptions of idiosyncratic deals may increase employees' trust in their employers and cement their bonds with them (Rousseau, 2005)" (Ng and Feldman, 2010, p. 420). They will indirectly influence organizational commitment through PCs because "the state of the psychological contract in terms of fulfillment or breach will result in positive or negative employee attitudes, 
respectively, which in turn will have an impact on employees in fulfilling their promises" (Katou and Budhwar, 2012, p. 796). Thus, we argue that organizational commitment is the heart that joins career i-deals and psychological contract. Accordingly, we hypothesize that:

Hypothesis 2: (a) Career i-deals are positively related to organizational commitment and employer and employee promises fulfillment, and (b) organizational commitment will mediate the relationship between employer and employee promises fulfillment.

\section{Organizational commitment, psychological contract and $O C B$}

It is generally accepted that those employees who will get i-deals may feel obliged to their employer and in return they will react positively (Anand et al., 2010). Although there are many types of employee outcomes considered individually in studies, we focus on the attitudinal outcome of organizational commitment and the behavioral outcome of OCB. $O C B$ refers to work behavior that exceeds what is dictated by the job description (Organ, 1988), and usually is described with the five dimensions of altruism (i.e., behaving in a way that demonstrates selflessness and concern for the welfare of others), courtesy (i.e., taking actions that help prevent problems of occurring, or taking advance actions to mitigate a problem), sportsmanship (i.e., choosing not to complaint or act in negative ways), conscientiousness (i.e., exhibiting commitment to high levels of work quality and completion), and civic virtue (i.e., adopting a posture of responsible, constructive involvement in the political or governance process of the organization) (Somech and Drach-Zahavy, 2018, p. 529).

I-deals are known to influence PCs, however, most studies have focused on the implications of their breach or violation instead of their fulfillment (Nelson and Tonks, 2007). This study focuses on the fulfillment of PCs in terms of both the employer and the employee fulfillment (De Jong, Schalk, and de Cuyper, 2009). This is because the fulfillment of promises influences more heavily PC outcomes than promises as such (Lambert, Edwards, and Cable, 
2003). In particular, based on the SET, it is argued that fulfillment of the PC positively influences employee outcomes (Gardner, Huang, Niu, Pierce, and Lee, 2015), because this fulfillment is reciprocated by employee motivation, commitment, satisfaction and OCB (Agarwal, 2014; Coyle-Shapiro and Kessler, 2002). "Nearly all conceptualizations of the psychological contract emphasize two elements of the employee psychological contract: the 'taking' of employer inducements obligates the employee to 'give' in terms of contributions" (Bordia et al., 2014, p. 3). In particular, in less competitive labor markets, employees are strongly interested in engaging more to relational than to transactional psychological contracts, inferring that the type of the employer-employee relationship is of social exchange nature (Lee and Hui, 2011; Rousseau et al., 2009).

We argued previously that career i-deals directly influence organizational commitment (Ng and Feldman, 2010). However, taking into consideration that attitudinal outcomes predict behavioural outcomes (Guest, 1997), we argue that organizational commitment predicts OCB. Combining these two relationships we argue that organizational commitment mediates the relationship between career i-deals and OCB. Accordingly, we hypothesize that:

Hypothesis 3: (a) Organizational citizen behavior is positively related to employer and employee promises fulfillment, and (b) organizational commitment will mediate the relationship between career i-deals and organizational citizen behavior.

Based on the above-presentation, Figure 1 presents our conceptual and hypothesized model.

\section{INSERT FIGURE 1 ABOUT HERE}

\section{Method}

Sample and procedure

Survey data were collected between October and December 2015 from 400 private firms with more than 20 employees operating in three Greek sectors (manufacturing, services, and trade). 
For increasing the reliability of measures (Gerhart, Wrigth, McMaham, and Snell, 2000) and the generalization of conclusions (Hochwarter, 2014), we collected at least 10 responses from three actors within each firm (senior managers, middle managers, low level employees). We managed to get 1768 questionnaires from 162 firms, resulting in 40.50 percent firm level response rate and 44.2 percent employee level response rate.

The distribution of the 162 sample organizations is as follows: 75.9 percent had 20 to 100 employees, 14.2 percent had 101 to 200 employees, and 9.9 percent had more than 200 employees; 18.5 percent were manufacturing firms, 35.8 percent services firms, and 45.7 percent trade firms. The characteristics of the 1768 sample respondents are as follows: 54.3 percent were male, and 45.7 percent female; 2.1 percent had elementary education, 31.2 percent high school / lyceum education, and 66.7 percent had college / university degree. The average age of respondents was $37.22( \pm 9.81)$ years old, and the average seniority was $8.61( \pm 7.58)$ years. 84.0 percent had full-time contract and 16.0 percent had part-time contract. Finally, 19.2 percent were senior managers, 20.4 percent were middle managers, and 60.5 percent were lower level employees.

\section{Measures}

Unless otherwise indicated, we used a five-level Likert scale and/or a five-point ordinal scale.

I-deals timing: We followed Rousseau et al. (2009) for measuring ex-ante (Cronbach's $\alpha=0.915)$ and ex-post $(\alpha=0.896)$ negotiation. Each dimension had two items.

I-deals content: We followed Hornung et al. (2014) for measuring career support $(\alpha=0.894)$.

Psychological contract: This scale was developed following the CIPD (2012) fact sheet. In particular, the employer promises fulfillment (PF) construct $(\alpha=0.806)$ comprised of transactional $(\alpha=0.878)$ and relational $(\alpha=0.922) \mathrm{PF}$, and the employee promises fulfillment construct $(\alpha=0.763)$ comprised of transactional $(\alpha=0.767)$ and relational $(\alpha=0.864)$ PF. 
Attitudinal employee outcomes: The organizational commitment scale $(\alpha=0.754)$ developed by Allen and Meyer (1990), has three sub-scales - affective commitment ( $\alpha=0.918)$, continuance commitment $(\alpha=0.714)$, and normative commitment $(\alpha=0.706)$.

Behavioral employee outcomes: The $O C B$ scale $(\alpha=0.795)$ developed by Niehoff and Moorman (1993), has the five sub-scales of altruism $(\alpha=0.868)$, courtesy $(\alpha=0.799)$, sportsmanship ( $\alpha=0.806)$, conscientiousness $(\alpha=0.771)$, and civic virtue $(\alpha=0.854)$.

Many controls influence the i-deals - outcomes relationship (Ng and Feldman, 2010). These controls are usually classified between organizational controls (e.g., sector, size), personal controls (e.g., gender, age, education), and employment individual controls (e.g., tenure, seniority, hierarchy).

\section{Data properties and statistical analysis}

All Cronbach alphas reported previously are higher than 0.70 , indicating construct internal consistency. In Table 1, the values of the average variances extracted (AVE) obtained by confirmatory factor analysis (CFA) are presented. All these values are higher than 0.50 , indicating that the instrument construct validity is acceptable (Hair, Anderson, Tatham, and Black, 2008). Additionally, in Table 1 the composite reliability scores are reported. Considering that these scores are very close to 0.90 , they indicate that construct composite reliability is adequate (Pavlou and Gefen, 2005). Finally, the correlation coefficients between all constructs used in the study are also reported in Table 1 . All these coefficients are smaller than the square root of the corresponding AVE, ensuring that the constructs are separate (Hair et al., 2008).

\section{INSERT TABLE 1 ABOUT HERE}

Considering the hierarchical nature of our data, with employees nested within organizations, we adopted multilevel structural equation modeling (MSEM) via Mplus (Muthen and Muthen, 2014) in testing our multilevel model (MLM). 


\section{Results}

The measurement model

While testing the hypothesized structure, the analyses showed acceptable fit (ChiSquare $=1332.584 \mathrm{df}=404, \mathrm{p}=0.000$, Normed-Chi-Square=3.298, RMSEA=0.036, CFI=0.947, TLI=0.934, SRMR-within=0.039, SRMR-between=0.120). Further, we examined all factor loadings and their squares for evaluating indicator reliability and we conclude that all measures are meaningfully related to their proposed latent dimensions. Next, we compared the fit of the proposed measurement model to an alternative less restrictive model, with all items loading on a single factor. This model was found to fit worse than the hypothesized model (ChiSquare $=8825.286 \mathrm{df}=460, \mathrm{p}=0.000$, Normed-Chi-Square $=19.185, \mathrm{RMSEA}=0.101, \mathrm{CFI}=0.523$, TLI=0.475, SRMR-within=0.128, SRMR-between=0.499), supporting the proposed factor structure of the constructs used in this study. Additionally, comparing the results of these two MCFA (i.e. $\Delta$ chi-square $=7492.702, \Delta \mathrm{df}=56, \Delta$ ratio $=\Delta$ chi-square $/ \Delta \mathrm{df}=133.798$ ), we conclude that the latent factors represent distinct constructs and that common method bias is limited because the $\Delta$ ratio=133.798 is much larger that the critical value of 3.84 per degree of freedom (see Brown, 2015).

\section{Structural model}

Before estimating the operational model, we investigated the necessary conditions justifying multilevel analysis. The intra-correlation coefficients ICC1 found to range between 0.128 (for self-esteem) and 0.249 (for affective commitment). Because these values are larger than 0.10, there is sufficient between-unit variation to justify multilevel analysis. The intra-correlation coefficients ICC2 found to range between 0.784 (for altruism) and 0.986 (for civic virtue). Because these values are larger than 0.50, the constructs ensure that there is sufficient withinunit agreement to justify aggregation. Similarly, the inter-rater agreement measures $r_{w g}(j)$ found to range between 0.786 (for employer promises fulfillment) and 0.967 (for OCB). As these 
values are larger than 0.70 , the constructs ensure that there is also sufficient within-unit agreement to justify aggregation (see Kozlowski and Klein, 2000).

In estimating the operational model of the study, we estimated two MLM: a CSE moderating model, as it is presented in Figure 1, and a mediating model treating CSE as an independent construct. With respect to the moderating model, the fit indices were very poor (Chi-Square $=16072.752, \mathrm{df}=548, \mathrm{p}=0.000$, Normed Chi-Square=29.330, RMSEA=0.127, $\mathrm{CFI}=0.563, \mathrm{TLI}=0.505, \mathrm{SRMR}-$ within=0.212, SRMR-between=0.237) and the interaction terms of $\operatorname{CSE} \times($ Ex-ante negotiation) and $\operatorname{CSE} \times($ Ex-post negotiation $)$ were not significant. Thus, we turned to the mediating model. Figures 2 and 3 present the MLM estimation results for the within and the between dimensions of the mediating operational model respectively, where all the variables included were significant. Given the fit indices (Chi-Square $=1902.685$, $\mathrm{df}=460, \mathrm{p}=0.000$, Normed Chi-Square=4.136, RMSEA=0.042, CFI=0.919, TLI=0.907, SRMR-within=0.086, SRMR-between=0.163), the variety of information and the sensibility of estimates, we can accept the model as a plausible representation of the data.

\section{INSERT FIGURES 2 AND 3 ABOUT HERE}

\section{Testing the hypotheses}

The results reported in Figure 2 (within) indicate that both ex-ante and ex-post negotiation predict career i-deals, and in Figure 3 (between) ex-post negotiation predicts career i-deals. However, hypothesis 1 is not supported, as we previously mentioned, the interaction effects between CSE and ex-ante or ex-post constructs were not significant. On the contrary, CSE as an independent construct strongly predicts career i-deals. Thus, we may say that this result verifies the view of existing research (e.g., Judge et al., 1998) that CES independently influences employee outcomes. Moreover, utilizing a paired t-test between the means presented in Table 1, we see that the extent of ex-post negotiation (mean $2.874 \pm 0.713$ ) is significantly larger than the extent of ex-ante negotiation (mean 2.618 \pm 0.801 ). This means that this finding, 
which holds for completive labor markets (Rousseau et al., 2009) is also true for less competitive labor markets. This is perhaps due to the dynamic on-going nature of ex-post negotiation compared to the static nature of ex-ante negotiation. Additionally, we see that employment conditions constitute the prevailing factor in ex-ante negotiation whilst work arrangements constitute the prevailing factor in ex-post negotiation, self-esteem is the prevailing factor in CSE, and development opportunities is prevailing factor in career i-deals.

Results reported in Figure 2 indicate that career i-deals are positively related to organizational commitment and employer promises fulfillment, whilst results in Figure 3 indicate that career i-deals positively predict only employer promises fulfillment. Thus, hypothesis 2(a) is partially supported. In terms of the structure of PC, we see that both in Figure 2 and 3 organizational commitments mediate the relationship between employer and employee promises fulfillment, supporting thus hypothesis 2(b). In particular, considering Figure 2, we see that organizational commitment partially mediates the relationship between employer and employee promises fulfillment (total $=0.645$, total indirect $=0.236, \mathrm{p}=0.000$ ), and employer promises fulfillment partially mediates the relationship between career-ideals and organizational commitment (total $=0.544$, total indirect $=0.339, \mathrm{p}=0.000$ ). Considering Figure 2, we see that organizational commitment fully mediates the relationship between employer and employee promises fulfillment (total $=0.779$, total indirect $=0.779, \mathrm{p}=0.000$ ), and employer promises fulfillment fully mediates the relationship between career-ideals and organizational commitment (total $=0.682$, total indirect $=0.682, \mathrm{p}=0.000$ ). Additionally, we see that affective commitment constitutes the prevailing factor in organizational commitment, and relational PC constitutes the prevailing factor in both employer and employee promises fulfillment.

Results reported in Figure 2 and Figure 3 indicate that OCB is positively and directly related to employee promises fulfillment only, thus, partially supporting hypothesis 3(a). Additionally, taking into consideration the "small picture" of the mediation mechanism, we see 
that organizational commitment mediates the relationship between career i-deals and OCB according to the results in Figure 2, and it is not mediating this relationship according to the results of Figure 3. However, taking into consideration the "large picture" of the mediation mechanism, we see that in both Figure 2 and Figure 3 results, organizational commitment mediates the relationship between career i-deals and OCB. This is because for Figure 2 we get a significant serially mediating mechanism (total $=0.416$, total indirect $=0.416, p=0.000$ ), and a similar mediating mechanism for Figure 3 (total $=0.533$, total indirect $=0.533, \mathrm{p}=0.000$ ). Therefore, hypothesis 3(b) is supported. Additionally, we see that courtesy constitutes the prevailing factor in OCB.

Finally, considering the controls used in the study, the significant results derived are those presented in Figure 2 and refer to the position of the individual. From these results we see that negotiation is weaker for non-managerial employees, and non-managerial employees seem to have lower self-evaluation.

\section{Discussion}

Grounded in the social exchange theory, the purpose of this study is to investigate the relationship between the timing of i-deals negotiation and $\mathrm{OCB}$, for understanding the employment relationship in Greece, which is under severe economic and financial crises. Completeness is the major asset of this study since it incorporates in the proposed model: (1) timing of i-deals expressed by both ex-ante and ex-post negotiations; (2) content of i-deals referring to career i-deals; (3) CSE as a possible moderating factor when negotiating career ideals; (4) both employer and employee perspectives of PC fulfillment; (5) employee attitudinal mediating outcomes such as organizational commitment, and (6) employee behavioral ultimate outcomes, such as OCB. Therefore, this study augments the relevant literature and offers a number of both theoretical and practical implications. 


\section{Theoretical implications}

Considering that the literature is limited in relating i-deals to PC (Liao et al., 2016), our study advances the debate by arguing that i-deals influence the formation of psychological contracts in less competitive labor markets due to economic and financial crises and the resultant high uncertainties. Rousseau and Greller (1994) argue that PCs constitute a system of individual's beliefs with respect to the terms and conditions of an exchange agreement between the individual and the organization. This system is subjective, and it is shaped by the general practices the organization is advancing aiming at all individuals. In our study we argue that it is not only the general practices the organization is advancing aiming at all individuals, but it is also the specific practices reflected in i-deals that the organization advances aiming at specific individuals. Thus, we argue that PCs have two dimensions based on the initiating factors that shape them: the general (as a result of the practices aiming at all individuals) and the specific (as a result of i-deals aiming at specific individuals). In our study, we have concentrated on the career i-deals specific dimension of PCs. It would be interesting for future research to investigate and compare the effects of these two dimensions of PCs.

It is usually argued that the reactions of individuals to events are influenced by how worthy they view themselves (Chang, Ferris, Johnson, Rosen, and Tan, 2012). In this study we found that although CSE is not moderating the relationship between timing of negotiation and career i-deals, when CSE, and especially self-esteem of individuals is improving then they achieve better career i-deals, and especially development opportunities. Thus, we suggest that future research should investigate the moderating - mediating alternatives in the relationship between timing of negotiation and career or other i-deals.

Responding to calls for more studies investigating the effects of i-deals on the employment relationship (e.g., Liao et al., 2016), we included in our investigation two relevant mediating relationships: the career i-deals and OCB relationship through organizational 
commitment; and the employer employee promises fulfillment relationship through organizational commitment. We found that career i-deals create a work environment that brings out bonds between PC and attitudinal and behavioural outcomes. In particular, bearing in mind that career i-deals influence PCs, we argue that not only the results of PCs are based in social exchange theory but also the results of both career i-deals and PCs are based in this theory. This is reflected in the finding that organizational commitment constitutes the "heart mediating bond" of two distinct relationships: the first is between employer and employee promises fulfillment, and the other is between career i-deals and OCB. Thus, future research would benefit from examining this "heart mediating bond".

However, we further argue that "social" exchange is framed within the "social context" where i-deals and PCs refer. In other words, we agree with the extant literature that in competitive labor markets (like those of the western economies) at the time of ex-ante negotiation individuals are more likely to engage in transactional PCs and at the time of expost negotiation individuals are more likely to engage in relational PC (Rousseau et al., 2009). In contrast, we argue that this picture is reversed when we refer to the Greek context. This is because in its labor market, where unemployment is high, individuals are looking for i-deals, such as career i-deals, that will ensure security (e.g., tenure) for the rest of their working life. This means that individuals are more engaged in relational than in transactional PCs. This is also evident from our findings, which indicate that PCs are more influenced by ex-ante negotiation (when referring to within individuals estimation), and more influenced by ex-post negotiation (when referring to between organizations estimation). Accordingly, we believe that we have provided evidence that in contexts of high uncertainties the influence of ex-ante and ex-post negotiation on transactional and relational PC is reversed in comparison with their influence in competitive labor markets. In other words, crises change the psychological state of people, who in turbulent times chose more security than money. 


\section{Managerial implications}

Based on the findings that apart of ex-ante and ex-post negotiation, CSE constitutes a largely significant personality factor in shaping career i-deals, and that career i-deals create a work environment that ties together PC and attitudinal and behavioural outcomes, the role of managers is very important in translating negotiation into obtainment (Rofcanin, Kiefer, and Strauss, 2017), in contexts with high uncertainties such as Greece. First, managers having granted career i-deals should fulfill their promises, because this fulfillment will activate employee organizational commitment, that in turn, will push employees also to fulfill their promises (Katou and Budhwar, 2012). Second, considering that in turbulent times, employee work safety via career development i-deals is of high importance to employees, managers should support the building of relational PCs, since these contracts by producing a feeling of security to employees makes them to reciprocate accordingly. Third, considering that "workers are more likely to attribute their ex-post i-deals to the quality of their relationship with their employers" (Rousseau, 2006, p. 983), managers should enhance this attribute by trying to improve the employment relationship. Fourth, although employees asking for ex-ante career ideals are in a weak negotiating position when unemployment is high, managers should try professionally to ascertain the positive characteristics of the prospective employees.

\section{Limitations}

This study has a number of limitations. First, the cross-sectional nature of the data could imply a contrary sequence of events and accordingly it is very difficult to support dynamic causal inferences. Therefore, future studies should focus on longitudinal data, which give the opportunity to investigate the lagged effects of i-deals negotiation on employee attitudinal and behavioral outcomes through PCs that in turn improve organizational performance. Second, although the estimation methodology followed is based on MLM, the use of self-reporting multiple respondents within senior managers, middle managers, and other employees in each 
firm may have not eliminated common method bias. Third, following Shaufely (2015), in estimation we allowed correlations between pairs of associated errors of constructs (e.g., exante and ex-post negotiation), taking into consideration that there is possibly no clear-cut between some latent constructs. Fourth, all variables were reported in retrospect, raising measurement concerns (especially for the ex-ante negotiation) about recall bias (Lippman and Mackenzie, 1985). Finally, in generalizing the results of this study, future research should be directed to countries that experience similar economic and financial crises or economic depression.

\section{Conclusion}

In an effort to uncover the positive impact of i-deals on organizational performance, previous research has provided wide-ranging empirical evidence of i-deals on employee outcomes. The current study is to some extent analogous with Rousseau et al. (2009), who examined the influence of timing of negotiation on social and economic exchange, through the mediating influence of work hour and development i-deals, and Lee and Hui (2011), who examined the influence of employee characteristics on employer and employee PCs, through the mediating influence of timing and content of i-deals. As indicated above, our model is comprehensive since it integrates important and related sets of constructs. Although the data used is from the Greek context, which is experiencing high unemployment and "other work anomalies, such as the widespread underpayment of high performers relative to low performers" (Rousseau, 2005 cited in Anand et al., 2010) due to a severe economic and financial crisis, the model connecting career i-deals with attitudinal and behavioral employee outcomes seemed to work rather well in this less competitive labor market, supporting that "i-deals are not limited to workers in competitive markets" (Hornung et al., 2008, p. 661). In particular, taking into consideration the purpose of the study, we believe that career i-deals content, which is objective in nature, and employer and employee PC fulfillment, which is subjective in nature, constitute the mediating 
epicenter of the timing of negotiation and employee outcomes relationship. Moreover, the study supports the view that context constitutes a critical factor in studying i-deals. In other words, competitive versus less competitive labor markets due to various forms of crisis where organizations are operating should be considered when studying i-deals.

\section{References}

Agarwal, U.A. (2014), 'Linking Justice, Trust and Innovative Work Behaviour to Work Engagement,' Personnel Review, 43, 1, 41-73.

Anand, S., Vidyarthi, P.R., Liden, R.C., and Rousseau, D.M. (2010), 'Good Citizens in PoorQuality Relationships: Idiosyncratic Deals as a Substitute for Relationship Quality. Academy of Management Journal, 53, 5, 970-988.

Allen, N.J., and Meyer, J.P. (1990), 'The Measurement and Antecedents of Affective, Continuance, and Normative Commitment to the Organization,' Journal of Occupational and Organizational Psychology, 63, 1, 1-18.

Bal, P.M., and Dorenbosch, L. (2015), 'Age-Related Differences in the Relations between Individualised HRM and Organisational Performance: A Large-Scale Employer Survey,' Human Resource Management Journal, 25, 1, 41-61.

Bal, P.M., De Jong, S.B., Jansen, P.G.W., and Bakker, A.B. (2012), 'Motivating Employees to Work Beyond Retirement: A Multi-Level Study of the Role of I-Deals and Unit Climate,' Journal of Management Studies, 49, 2, 306-331.

Bellos, I. (2017), 'Business Sector in Greece Shrank by Over 244,000 Firms in Just Seven Years,' ekathimerini.com, May 11 (www.ekathimerini.com/208159/article/).

Blau, P. (1964), Exchange and Power in Social Life. New York: Wiley.

Bordia, P., Restubog, S.L.D., Bordia, R.L., and Tang, R.L. (2014), 'Effects of Resource Availability on Social Exchange Relationships: The Case of Employee Psychological 
Contract Obligations,' Journal of Management, 43, 5, 1447-1471.

Briscoe, J.P., and Hall, D.T. (2006), 'The Interplay of Boundaryless and Protean Careers: Combinations and Implications,' Journal of Vocational Behavior, 69, 1, 4-18.

Brown, T.A. (2015), Confirmatory Factor Analysis for Applied Research, $2^{\text {nd }}$ ed., London: The Guilford Press.

Busse, C., Kach, A.P., and Wagner, S.M. (2017), 'Boundary Conditions: What they are, How to Explore Them, Why we Need them, and When to Consider Them,' Organizational Research Methods, 20, 4, 574-609.

Chand, M.D., Budhwar, P.S., and Katou, A.A. (2017), 'Investigating idiosyncratic deals in the Indian hospitality industry', in Opportunities and Challenges for Tourism and Hospitality in the BRIC Nations, ed. M.D. Chand, IGI-Global, pp. 221-238.

Chang, C.-H., Ferris, D.L., Johnson, R.E., Rosen, C.C., and Tan, J.A. (2012). 'Core SelfEvaluations: A Review and Evaluation of the Literature,' Journal of Management, 38, 1, $81-128$.

CIPD. (2012), The Psychological Contract, London: Chartered Institute of Personnel and Development.

CIPD. (2016), Understanding the Economy and Labour Market, London: Chartered Institute of Personnel and Development.

Conway, N., and Briner, R.B. (2005), Understanding Psychological Contracts at Work. Oxford, England: Oxford University Press.

Coyle-Shapiro, J.A.-M., and Conway, N. (2005), 'Exchange Relationships: Examining Psychological Contracts and Perceived Organizational Support,' Journal of Applied Psychology, 90, 4, 774-781.

Coyle-Shapiro, J.A.-M., and Kessler, I. (2002), 'Consequences of the Psychological Contract for the Employment Relationship: A Large Scale Survey,' Journal of Management Studies, 
$37,7,903-930$.

De Jong J., Schalk, R., and de Cuyper, N. (2009), 'Balanced Versus Unbalanced Psychological Contracts in Temporary and Permanent Employment: Associations with Employee Attitudes,' Management and Organization Review, 5, 3, 329-351.

Gardner, D.G., Huang, G.-H., Niu, X., Pierce, J.L., and Lee, C. (2015), 'Organization-Based Self-Esteem, Psychological Contract Fulfillment, and Perceived Employment Opportunities: A Test of Self-Regulatory Theory,' Human Resource Management, 54, 6, 933-953.

Gerhart, B., Wrigth, P.M., McMaham, G.C., and Snell, S.A. (2000), 'Measurement Error in Research on Human Resources and Firm Performance: How Much Error is there and how does it Influence Effect Size Estimates?' Personnel Psychology, 53, 4, 803-834.

Greene, W.H. (2012), Econometric Analysis, $7^{\text {th }}$ ed., New York: Pearson.

Guerrero, S., Bentein, K., and Lapalme, M.-E. (2014), 'Idiosyncratic Deals and High Performers' Organizational Commitment,' Journal of Business Psychology, 29, 2, 323-334.

Guest, D. (1997), 'Human Resource Management and Performance: A Review and Research Agenda,' International Journal of Human Resource Management, 8, 3, 263-276.

Guest, D.E. (2004), 'The Psychology of the Employment Relationship: An Analysis Based on the Psychological Contract,' Applied Psychology: An International Review, 53, 4, 541-555.

Hair, F., Anderson, R., Tatham, R., and Black, W. (2008), Multivariate Data Analysis with Readings. London: Prentice-Hall.

Harman, H.H. (1967), Modern Factor Analysis. Chicago, IL: University of Chicago Press. Ho, V.T., and Kong, D.T. (2015), 'Exploring the Signaling Function of Idiosyncratic Deals and their Interaction,' Organizational Behavior and Human Decision Processes, 131, 149-161. Hochwarter, W. (2014), 'On the Merits of Student-Recruited Sampling: Opinions a Decade in the Making,' Journal of Occupational and Organizational Psychology, 87, 1, 27-33. 
Hornung, S., Rousseau, D.M., and Glaser, J. (2008), 'Creating Flexible Work Arrangements through Idiosyncratic Deals,' Journal of Applied Psychology, 93, 3, 655-664.

Hornung, S., Rousseau, D.M., and Glaser, J. (2009), 'Why Supervisors Make Idiosyncratic Deals: Antecedents and Outcomes of I-Deals from a Managerial Perspective,' Journal of Managerial Psychology, 24, 8, 738-764.

Hornung, S., Rousseau, D.M., Glaser, J., Angerer, P., and Weigl, M. (2010), 'Beyond TopDown and Bottom-Up Work Redesign: Customizing Job Content through Idiosyncratic Deals,' Journal of Organizational Behavior, 13, 2-3, 187-215.

Hornung, S., Rousseau, D.M., Weigl, M., Muller, A., and Glaser, J. (2014), 'Redesigning Work through Idiosyncratic Deals,' European Journal of Work and Organizational Psychology, $23,4,608-626$.

Judge, T.A., Locke, E.A., and Durham, C.C. (1997), 'The Dispositional Causes of Job Satisfaction: A Core Evaluations Approach,' Research in Organizational Behavior, 19, $151-188$.

Judge, T.A., Locke, E.A., Durham, C.C., and Kluger, A.N. (1998), 'Dispositional Effects on Job and Life Satisfaction: The Role of Core Evaluations,' Journal of Applied Psychology, $83,1,17-34$.

Kasekende, F., Munene, J.C., Ntayi, J.M., and Ahiauzu, A. (2015), 'The Interaction Effect of Social Exchanges on the Relationship Between Organizational Climate and Psychological Contract,' Leadership and Organizational Development Journal, 36, 7, 833-848.

Katou, A.A., and Budhwar, P.S. (2012), 'The Link between HR Practices, Psychological Contract Fulfilment and Organizational Performance: The Case of the Greek Services Sector,' Thunderbird International Business Review, 54, 6, 793-809.

King, Z. (2004), Career Management: A CIPD Guide. London: Chartered Institute of Personnel and Development. 
Kousta, E., and Stamati, A. (2012), 'The Impact on Labor Relations under the Threat of Unemployment during the Recession and the Crisis,' Greek Labor Institute, 36, 87-155.

Kozlowski, S.W. and Klein, K.J. (2000), 'A multilevel approach to theory and research in organizations: Contextual, temporal, and emergent processes,' in K.J. Klein and S.W.J. Kozlowski (Eds.), Multilevel Theory, Research, and Methods in Organizations: Foundations, Extensions, and New Directions, San Francisco: Jossey-Bass, pp. 3-90.

Kroon, B., Freese, C., and Schalk, R. (2015), 'A Strategic HRM Perspective on I-deals,' in Idiosyncratic Deals between Employees and Organizations: Conceptual Issues, Applications, and the Role of Coworkers, eds. P.M. Bal and D.M. Rousseau, London: Psychology Press, pp. 92-106.

Lai, L., Rousseau, D.M., and Chang, K.T.T. (2009), 'Idiosyncratic Deals: Coworkers as Interested Third Parties,' Journal of Applied Psychology, 94, 2, 547-556.

Lambert, L.S., Edwards, J.R., and Cable, D.M. (2003), 'Breach and fulfilment of the Psychological Contract: A Comparison of Traditional and Expanded Views,' Personnel Psychology, 56, 4, 895-934.

Las Heras, M., Rofcanin, Y., Bal, M.B., and Stollberger, J. (2017a), 'How do Flexibility IDeals Relate to Work Performance? Exploring the Roles of Family Performance and Organizational Context,' Journal of Organizational Behavior, 38, 8, 1280-1294.

Las Heras, M., van der Heijden, B., de Jong, J., and Rofcanin, Y., (2017b), 'Handle with Care: The Mediating Role of I-Deals in the Relationship between Supervisors' Care-Giving Responsibilities and Employee Outcomes,' Human Resource Management Journal, 27, 3, 335-349.

Lee, C., and Hui, C. (2011), 'Antecedents and Consequences of Idiosyncratic Deals: A Frame of Resource Exchange,' Frontiers of Business Research, 5, 3, 380-401.

Lee, C., Liu, J., Rousseau, D.M., Hui, C., and Chen, Z.X. (2011), 'Inducements, Contributions, 
and Fulfillment in New Employee Psychological Contracts,' Human Resource Management, 50, 2, 201-226.

Liao, C., Wayne, S.J., and Rousseau, D.M. (2016), 'Idiosyncratic Deals in Contemporary Organizations: A Qualitative and Meta-Analytical Review,' Journal of Organizational Behavior, 37, S9-S29.

Lippman, A., and Mackenzie, S.G. (1985), 'What is "recall bias" and does it exist?' in M. Marois (ed.), Prevention of Physical and Mental Congenital Defects: Part C. Basic and Medical Science, Education, and Future Strategies, New York. pp. 205-209.

Liu, J., Lee, C., Hui, C., Kwan, H.K., and Wu, L.-Z. (2013), 'Idiosyncratic Deals and Employee Outcomes: The Mediating Roles of Social Exchange and Self-Enhancement and the Moderating Role of Individualism,' Journal of Applied Psychology, 98, 5, 832-840.

Marescaux, E., De Winne, S., and Sels, L. (2019), 'Idiosyncratic Deals from a Distributive Justice Perspective: Examining Co-Workers' Voice Behavior,' Journal of Business Ethics, $154,1,263-281$.

McDonald, D.J., and Makin, P.J. (2000), 'The Psychological Contract, Organizational Commitment and Job Satisfaction of Temporary Staff,' Leadership and Organization Development Journal, 21, 2, 84-91.

Meijerink, J. (2014), Practicing Social Innovation: Enactment of the Employee-Organisation Relationship by Employees,' in Human Resource Management, Social Innovation and Technology, eds. T. Bondarouk and M.R. Olivas-Lujian (eds). Emerald Group Publishing Limited, pp. 135-153.

Meyer, J.P., and Allen, N.J. (1991), ‘A Three-Component Conceptualization of Organizational Commitment,' Human Resource Management Review, 1, 1, 61-89.

Muthen, L.K. and Muthen, B.O. (2014), Mplus Computer Software. Los Angeles, CA: Muthen \& Muthen. 
Nelson, L., and Tonks, G. (2007), 'Violations of the Psychological Contract: Experiences of a Group of Causal Workers,' Research and Practice in Human Resource Management, 15, 1, $22-36$

Ng, T.W.H., and Feldman, D.C. (2010), 'Idiosyncratic Deals and Organizational Commitment,' Journal of Vocational Behavior, 76, 3, 419-427.

Ng, T.W.H., and Feldman, D.C. (2012), 'Breaches of Past Promises, Current Job Alternatives, and Promises of Future Idiosyncratic Deals: Three-Way Interaction Effects on Organizational Commitment,' Human Relations, 65, 11, 1463-1486.

Ng, T.W.H., and Feldman, D.C. (2015), 'Idiosyncratic Deals and Voice Behavior,' Journal of Management, 41, 3, 893-928.

Ng, T.W.H., and Lucianetti, L. (2016), 'Goal Striving, Idiosyncratic Deals, and Job Behavior,' Journal of Organizational Behavior, 37, 1, 41-60.

Nijssen, M. and Paauwe, J. (2012), 'HRM in Turbulent Times: How to Achieve Organizational Agility?,' The International Journal of Human Resource Management, 23, 16, 3315-3335.

Niehoff, B.P., and Moorman, R.H. (1993), 'Justice as a Mediator of the Relationship Between Methods of Monitoring and Organizational Citizen Behaviour,' Academy of Management Journal, 36, 3, 527-556.

Organ, D.W. (1988), Organizational Citizenship Behaviour: The Good Solider Syndrome, Lexington, MA: Lexington Books.

Pavlou, P.A., and Gefen, D. (2005), 'Psychological Contract Violation in Online Marketplaces: Antecedents, Consequences, and Moderating Role,' Information Systems Research, 16, 4, 372-399.

Prouska, R. and Psychogios, A.G. (2018a), Do Not Say a Word! Conceptualizing Employee Silence in a Long-term Crisis Context, The International Journal of Human Resource Management, 29, 5, 885-914. 
Prouska, R. and Psychogios, A.G. (2018b), 'Should I Say Something? A framework for Understanding Silence from a Line Manager's Perspective During an Economic Crisis,' Economic and Industrial Democracy,

Psychogios, A. and Wood, G. (2010), 'Human Resource Management in Greece in Comparative Perspective: Alternative Institutionalist Perspectives and Empirical Realities,' International Journal of Human Resource Management, 21, 14, 2614-2630.

Psychogios, A., Nyfoudi, Theodorakopoulos, N., and Szamosi, R. (2019), 'Many Hands Lighter Work? Deciphering the Relationship between Adverse Working Conditions and Organization Citizenship Behaviours in Small and Medium-sized Enterprises during a Severe Economic Crisis,' British Journal of Management, 30, 3, 519-537.

Robinson, S.L., and Rousseau, D.M. (1994), 'Violating the Psychological Contract: Not the Exception but the Norm,' Journal of Organizational Behavior, 15, 3, 245-259.

Rofcanin, Y., Kiefer, T., and Strauss, K. (2017), 'What Seals the I-Deal? Exploring the Role of Employees' Behaviours and Managers' Emotions,' Journal of Occupational and Organizational Psychology, 90, 2, 203-24.

Rosen, C.C., Slater, D.J., Chang, C.-H., and Johnson, R.E. (2013), 'Let's Make a Deal: Development and Validation of the Ex Post I-Deals Scale,' Journal of Management, 39, 3, 709-742.

Rousseau, D.M (1990), 'New hire perceptions of their own and their employer's obligations: a study of psychological contracts,' Journal of Organisational Behaviour, 11, 389-400.

Rousseau, D.M. (1995), Psychological Contracts in Organisations: Understanding the Written and Unwritten Agreements. London: Sage.

Rousseau, D.M. (2001), 'The idiosyncratic deal: Flexibility versus fairness?' Organizational Dynamics, 29, 4, 260-273.

Rousseau, D.M. (2005), I-Deals: Idiosyncratic Deals Employees Bargain for Themselves. New 
York: M.E. Sharpe.

Rousseau, D.M., and Greller, M.M. (1994), 'Human Resource Practices: Administrative Contract Makers,' Human Resource Management, 33, 3, 384-401.

Rousseau, D.M., Ho, V.T., and Greenberg, J. (2006), 'I-deals: Idiosyncratic Terms in Employment Relationships,' Academy of Management Review, 31, 4, 977-994.

Rousseau, D.M., Hornun, S., and Kim, T.G. (2009), 'Idiosyncratic Deals: Testing Propositions on Timing, Content, and the Employment Relationship,' Journal of Vocational Behaviour, $74,3,338-348$.

Schaufeli, W.B. (2015), 'Engaging Leadership in the Job Demands-Resources Model,' Career Development International, 20, 5, 446-463.

Schaufeli, W.B., Salanova, M., Gonzalez-Roma, V., and Bakker, A.B. (2002), 'The Measurement of Engagement and Burnout: A two Sample Confirmatory Factor Analytic Approach,' Journal of Happiness Studies, 3, 1, 71-92.

Schlosser, F. and Zolin, R. (2012), 'Hearing Voice and Silence During Stressful Economic Times,' Employee Relations, 34, 5, 555-573.

Somech, A. and Drach-Zahavy, A. (2018), 'Rethinking organizational citizenship behavior in service organizations: Its nature and conceptualization,' in The Oxford Handbook of Organizational Citizenship Behavior, ed. P.M. Podsakoff, S.B. Mackenzie, and N.P. Podsakoff, N.P., Oxford University Press, pp. 527-542.

Sturges, J. (2012), 'Crafting a Balance between Work and Home', Human Relations, 65, 12, 1539-1559.

Sturges, J., Conway, N., Guest, D., and Liefoodghe, A. (2005), 'Managing the Career Deal: The Psychological Contract as a Framework for Understanding Career Management, Organizational Commitment and Work Behavior,' Journal of Organizational Behavior, 26, 7, 821-838. 
Suazo, M.M., Martinez, P.G., and Sandoval, R. (2009), 'Creating Psychological and Legal Contracts Through Human Resource Practices: A Signaling Theory Perspective,' Human Resource Management Review, 19, 2, 154-166.

Teague, P. and Roche, W.K. (2014), 'Recessionary Bundles: HR Practices in the Irish Economic Crisis,' Human Resource Management Journal, 24, 2, 176-192.

Wood, G., Cooke, F.L., Demirbag, M., and Kwong, C. (2018), 'International Journal of Human Resource Management (IJHRM) Special Issue on: International Human Resource Management in Contexts of High Uncertainties,' The International Journal of Human Resource Management, 29, 7, 1365-1373.

Wood, G., Szamosi, L.T., Psychogios, A., Sarvanidis, S. and Fotopoulou, D. (2015), 'Rethinking Greek Capitalism through the Lens of Industrial Relations Reform: A View Until the 2015 Referendum'. Relations Industrielles/Industrial Relations, 70, 4, 698-717.

Vidyarthi, P.R., Chaudhry, A., Anand, S., and Liden, R.C. (2014), 'Flexibility I-Deals: How Much is Ideal?' Journal of Managerial Psychology, 29, 3, 246-265. 


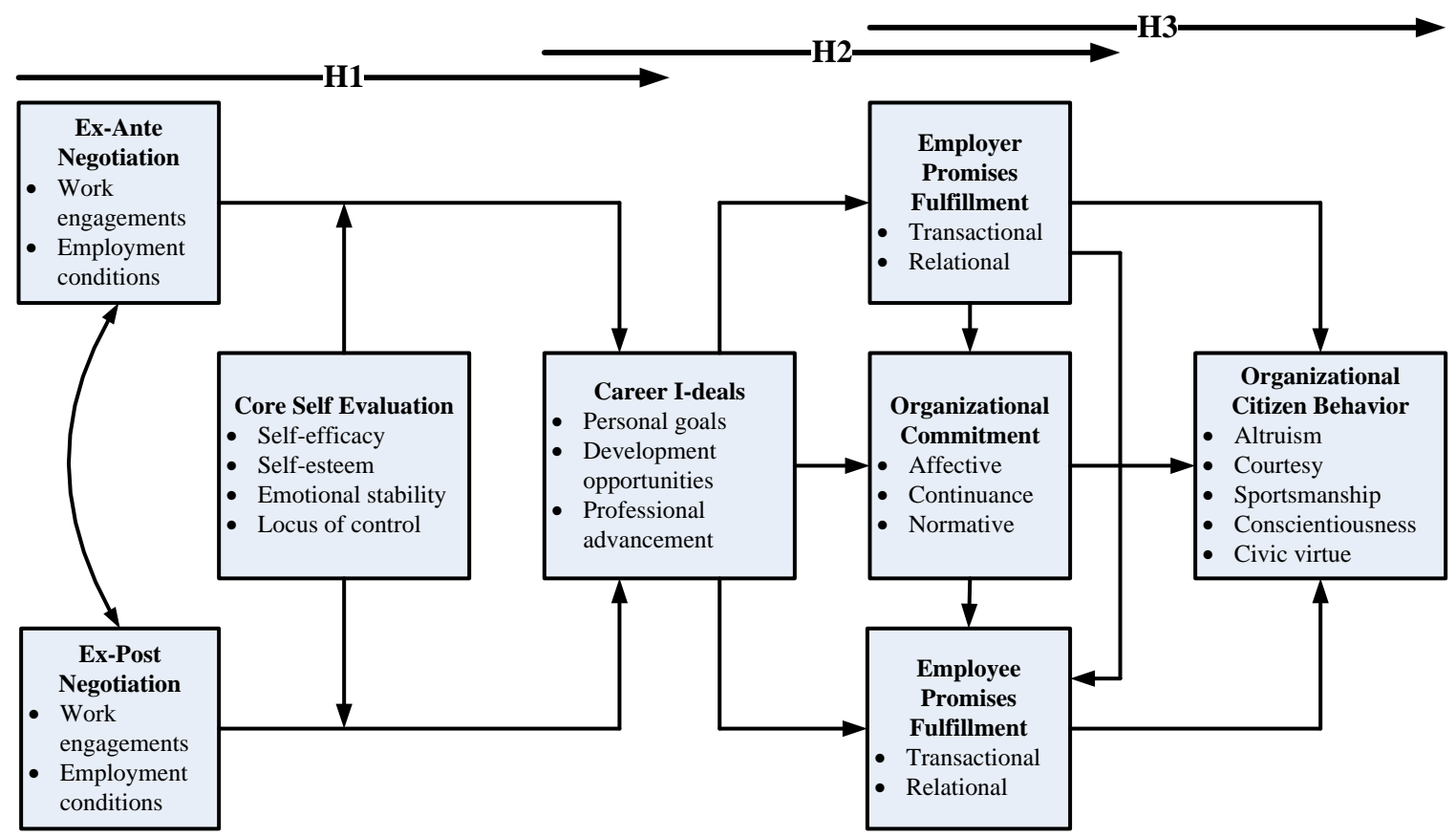

Figure 1. Operational model of the I-Deals - Employee Outcomes relationship 


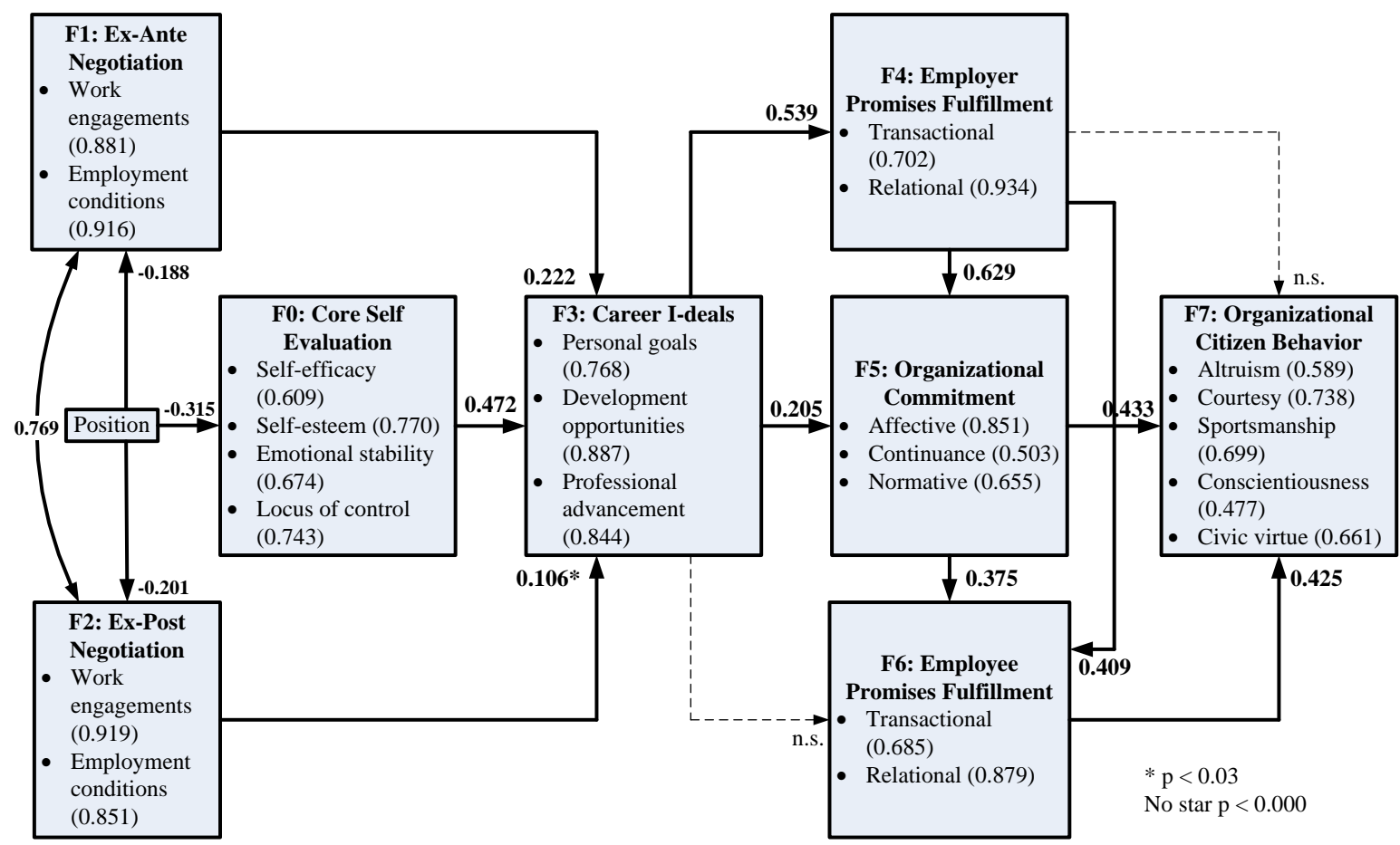

Figure 2. Within individuals estimation results of the Operational model of the I-Deals Employee Outcomes relationship 


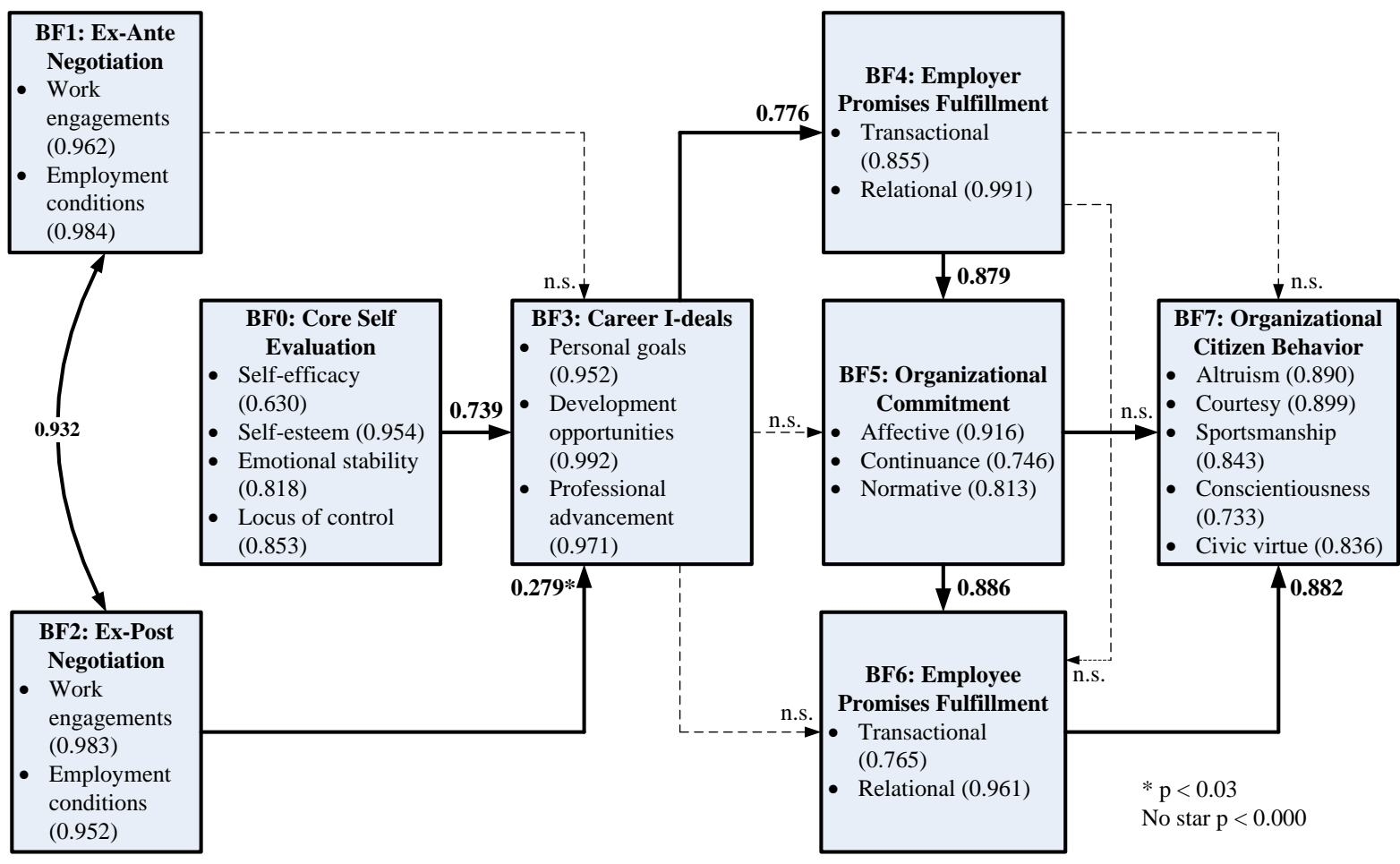

Figure 3. Between organizations estimation results of the Operational model of the I-Deals Employee Outcomes relationship 
Table 1. Means, standard deviations, reliability indices, and correlation coefficients of the constructs used in the study

\begin{tabular}{|c|c|c|c|c|c|c|c|c|c|}
\hline \multirow[t]{2}{*}{ Constructs } & \multirow{2}{*}{$\begin{array}{c}\text { Means } \\
\text { (standard } \\
\text { deviations) }\end{array}$} & \multirow[b]{2}{*}{$\begin{array}{l}\text { Construct } \\
\text { composite } \\
\text { reliability }\end{array}$} & \multicolumn{7}{|c|}{ Correlation coefficients } \\
\hline & & & $\begin{array}{c}\text { Ex-Ante } \\
\text { Negotiation }\end{array}$ & $\begin{array}{c}\text { Ex-Post } \\
\text { Negotiation }\end{array}$ & $\begin{array}{l}\text { Career } \\
\text { I-Deals }\end{array}$ & $\begin{array}{c}\text { Employer } \\
\text { Promises } \\
\text { Fulfillment }\end{array}$ & $\begin{array}{c}\text { Employee } \\
\text { Promises } \\
\text { Fulfillment }\end{array}$ & $\begin{array}{l}\text { Organizational } \\
\text { Commitment }\end{array}$ & OCB \\
\hline $\begin{array}{l}\text { Ex-Ante } \\
\text { Negotiation }\end{array}$ & $\begin{array}{l}2.618 \\
(0.801)\end{array}$ & 0.971 & {$[0.943]^{*}$} & & & & & & \\
\hline $\begin{array}{l}\text { Ex-Post } \\
\text { Negotiation }\end{array}$ & $\begin{array}{c}2.874 \\
(0.713)\end{array}$ & 0.961 & 0.730 & {$[0.925]$} & & & & & \\
\hline Career I-Deals & $\begin{array}{c}3.512 \\
(0.931)\end{array}$ & 0.934 & 0.382 & 0.364 & {$[0.863]$} & & & & \\
\hline $\begin{array}{l}\text { Employer } \\
\text { Promises } \\
\text { Fulfillment }\end{array}$ & $\begin{array}{l}3.696 \\
(0.840)\end{array}$ & 0.918 & 0.343 & 0.295 & 0.516 & {$[0.752]$} & & & \\
\hline $\begin{array}{l}\text { Employee } \\
\text { Promises } \\
\text { Fulfillment }\end{array}$ & $\begin{array}{c}4.034 \\
(0.613)\end{array}$ & 0.896 & 0.151 & 0.123 & 0.326 & 0.549 & {$[0.673]$} & & \\
\hline $\begin{array}{l}\text { Organizational } \\
\text { Commitment }\end{array}$ & $\begin{array}{c}3.841 \\
(0.660)\end{array}$ & 0.859 & 0.204 & 0.165 & 0.461 & 0.593 & 0.524 & [0.669] & \\
\hline OCB & $\begin{array}{c}4.123 \\
(0.537)\end{array}$ & 0.863 & 0.110 & 0.110 & 0.366 & 0.514 & 0.615 & 0.586 & {$[0.503]$} \\
\hline
\end{tabular}

Notes: All correlation coefficients are significant at $\mathrm{p}<0.01$

* Average Variance Extracted (AVE) 